\title{
TURYSTYKA POLSKICH SENIORÓW - EFEKTY PROJEKTU CALYPSO
}

\section{Projekt Calypso}

Jedną z inicjatyw podjętych przez Komisję Europejską w ostatnich latach $\mathrm{w}$ dziedzinie turystyki jest projekt Calypso. Jest to działanie przygotowawcze odnoszące się do turystyki społecznej w Europie przyjęte przez Parlament Europejski w 2008 r. na okres trzech lat. Calypso „skupia się na pozasezonowych przepływach turystów należących do czterech grup docelowych turystyki społecznej ${ }^{1}$, przy czym przepływy te obejmować muszą przynajmniej dwa państwa członkowskie lub kraje kandydujące" (Europa... 2010, s. 10). Jego założeniem jest wspieranie partnerstw między sektorem publicznym, prywatnym oraz gospodarką społeczna, inspirowanych przez Komisje Europejską (KE)². Celem Calypso jest wspieranie zatrudnienia, przeciwdziałanie sezonowości w turystyce, rozwój obywatelstwa europejskiego oraz po-

\footnotetext{
${ }^{1}$ Grupy docelowe turystyki społecznej (Calypso) to: seniorzy, młodzież (w wieku 18-30 lat), niepełnosprawne osoby dorosłe, rodziny (dzieci, rodzice i/lub dziadkowie) posiadający dokument organu krajowego koordynującego potwierdzający ich trudną sytuację (finansową osobistą lub niepełnosprawność) Działania ... 2010).

${ }^{2}$ Budżet, jaki przewidziano na ten cel w 2009 roku wyniósł 1 mln euro (http://ec.europa.eu).
} 
prawa stanu gospodarek regionalnych/lokalnych poprzez rozwój turystyki społecznej (http://ec.europa.eu). Poza tym program ma przyczynić się do aktywnego starzenia się społeczeństwa europejskiego, a całość podejmowanych działań ma być zgodna z zachowaniem kryteriów zrównoważonego rozwoju (Działania... 2010).

Zatwierdzony przez Parlament Europejski pilotażowy projekt pod nazwą Calypso został uruchomiony w drugiej połowie 2009 r. Polska przystąpiła do projektu i z widocznym zaangażowaniem uczestniczy w pracach nad jego kształtem. W ramach prac przygotowawczych organizowano seminaria informacyjne (np. w listopadzie 2009 roku w Warszawie przez Ministerstwo Sportu i Turystyki, następnie we Francji, Włoszech, Belgii, Rumunii, Hiszpanii) skierowane do partnerów lokalnych, branży turystycznej, stowarzyszeń, władz regionalnych i organizacji społecznych. Ich celem jest wspólne wypracowanie systemu rozwoju i wymiany w ramach europejskiej turystyki społecznej. Dzięki Calypso powstał m.in. spis dobrych praktyk stosowanych w państwach członkowskich. Jak podkreślono w komunikacie KE z 30.06. 2010 r., „istniejące dobre praktyki, zwłaszcza z Półwyspu Iberyjskiego, udowadniają że sektor publiczny może finansować takiego rodzaju mechanizmy i uzyskać pozytywny zwrot z inwestycji (ponad 1,5 euro za każde wydane euro), jeśli uwzględnić zyski wynikające $\mathrm{z}$ tworzenia nowych miejsc pracy, dodatkowe możliwości dla sektora prywatnego oraz przychody z podatków uzyskane dzięki nasileniu działalności gospodarczej. Korzyści te mają również pozytywny wpływ na kraj pochodzenia" (Europa... 2010, s. 10).

Komisja Europejska zleciła przeprowadzenie badań we wszystkich państwach unijnych uczestniczących $\mathrm{w}$ projekcie. Wyłonieni drogą przetargu konsultanci - Ramboll Management Consulting (Belgia) w konsurcjum z Détente Consultants (Francja), Universytetem Sapienza (Włochy) i Labour Associados (Hiszpania) przygotowali m.in. analizy profilów poszczególnych krajów (Calypso study on social tourism - Poland, 2010) oraz finalny raport ogłoszony podczas czerwcowej konferencji w Palma de Mallorca. Celem raportu było m.in. wskazanie realnych mechanizmów rozwoju struktur w państwach członkowskich, które będą koordynować wymianę grup (w ramach turystyki społecznej), jak i rozwiązań umożliwiających tym grupom (w tym osobom starszym) wyjazdy turystyczne do państw członkowskich w ramach programu. Warto zauważyć, że wspomniana konferencja zorganizowana pod koniec prezydencji hiszpańskiej w UE w 2010 r. bardzo wyraźnie korespondowała z jednym z priorytetów hiszpańskiego Ministerstwa Przemysłu, Turystyki i Handlu, jakim było „włączenie do polityki unijnej dotyczącej turystyki punktu widzenia prezentowanego przez sektor, a zwłaszcza promowanie europejskiej turystyki dla seniorów". W efekcie - opublikowany 
nowy komunikat KE dotyczący turystyki z dnia 30.06.2010 r. (Europa... 2010) wśród 21 propozycji działań na rzecz utrzymania pozycji Europy jako najpopularniejszego kierunku turystycznego na świecie uwzględnił jedno rozwiązanie nawiązujące bezpośrednio do projektu Calypso. Jest nim „przedłużenie sezonu turystycznego" założone poprzez usprawnienie programu wymiany turystycznej umożliwiającej młodym ludziom, osobom starszym, rodzinom o niskich dochodach oraz osobom o ograniczonej mobilności podróżowanie poza sezonem turystycznym.

\section{Profil polskiego seniora (według Calypso Study on Social Tourism, 2010)}

Według analizy przygotowanej dla Polski przez wspomnianych wcześniej konsultantów polscy seniorzy to grupa niejednolita. Jest to m.in. konsekwencją przyjętego w Polsce założenia, w myśl którego seniorem jest osoba powyżej 50 roku życia, podczas gdy w większości krajów UE wyznacznikiem wieku seniora jest osiągnięcie 65 lat $^{3}$. W populacji polskich seniorów wyraźnie wyodrębniają się dwie subpopulacje - pierwszą tworzy pokolenie przedwojenne (osoby urodzone w latach 20.-40. XX wieku), drugą pokolenie powojennego wyżu (urodzeni w latach 1946-19604). Pierwsza grupa jest ukierunkowana tradycyjnie i nie wykazuje, zdaniem autorów raportu, gotowości ponoszenia wydatków na turystykę, druga - o odmiennej sytuacji społecznej i nieco innych wartościach - przejawia wzrastające zainteresowanie turystyką w miarę swoich możliwości (autorzy raportu upatrują w tym zachowaniu m.in. efektu zamknięcia granic przed 1989 r.). Oszacowany miesięczny dochód polskiego seniora wynosi 306 euro. Według raportu, Polacy powyżej 50. roku życia najchętniej samodzielnie planują wyjazdy wypoczynkowe. Ze zorganizowanych form preferują sanatoria (dofinansowane przez NFZ). Jako nielicznych okazjonalnych organizatorów wypoczynku tej grupy

\footnotetext{
${ }^{3}$ Senior - słowo pochodzące z języka łacińskiego oznacza „starszy” (senex - stary). W literaturze marketingowej seniorami nazywa się osoby w wieku 60 lat i więcej. Jednocześnie można w obrębie tej grupy wyróżnić wiele różnych segmentów. Wśród licznych determinant zachowań rynkowych seniorów istotny jest według ŚNIADEK (2007) system wartości, który opiera się zarówno na wartościach uniwersalnych, jak i pokoleniowych. Te drugie są punktem wyjścia dla demografów, którzy wyróżniają grupy ze względu na tzw. kohorty. Obecne pokolenie seniorów to głównie pokolenie kohorty powojennej i wchodzące w wiek senioralny pokolenie baby-boomers (ŚNIADEK 2007).

4 Ogółem w okresie 1946-1960 w fazie powojennej kompensacji urodziło się 11,12 mln osób, spośród których po dziś dzień żyje około 8 mln (ŚNIADEK 2007).
} 
autorzy raportu wskazali lokalne organizacje, m.in. uniwersytety trzeciego wieku. Pominięto natomiast dość popularne w tym pokoleniu Polaków wyjazdy organizowane przez Kościół (KOWALCZYK-ANIOŁ 2007). W oparciu o dane Instytutu Turystyki wskazano jako dominujące wyjazdy krótkie (do pięciu dni), wśród krajowych najczęściej na wybrzeże Morza Bałtyckiego, Mazury i Podlasie, wśród zagranicznych do Czech i Słowacji, oraz równie istotne w ostatnich latach względnie tanie wyjazdy do ciepłych krajów - Tunezji, Egiptu, Grecji. Jedne i drugie przeważnie odbywane są w towarzystwie rodziny lub znajomych.

Średnie wydatki ponoszone podczas podróży krajowych przez polskich seniorów oszacowano na poziomie 15 euro na dzień, natomiast podczas wyjazdów zagranicznych 35 euro na dzień. Wśród innych cech wyróżniających analizowaną grupę podkreślono zwyczaj łączenia podróży wypoczynkowych z odwiedzinami krewnych i znajomych, jak i postrzeganie samych siebie jako „zbyt starych" i „zbyt chorych” aby podejmować wyjazdy. Wśród problemów i powodów braku wyjazdów tej grupy wskazano m.in. trudności $\mathrm{z}$ dostępem do transportu, problemy finansowe oraz niską wiedzę o potrzebach seniorów wśród pracowników obsługi turystycznej. Polscy seniorzy, w myśl prezentowanego raportu, wyraźnie wskazuja zainteresowanie tanimi podróżami do ciepłych krajów w okresie od jesieni do wiosny.

\section{Europe Senior Tourism}

Europe Senior Tourism jest przedsięwzięciem wpisującym się w ramy działań przygotowawczych Parlamentu i Komisji Europejskiej Calypso, które m.in. propagują wprowadzanie projektów turystyki społecznej wśród państw członkowskich, ze względu na wagę społeczną i gospodarcza, jaką posiadają projekty już istniejące (w przypadku Hiszpanii program IMSERSO 5 ). Program pilotażowy Europe Senior Tourism (EST) rozpoczął się 1 października 2009 r. Komercjalizacja projektu zajmowało się biuro Viajes Zoetrope, pod znakiem handlowym Travel Senior. Firma ta podpisała umowy z różnymi lokalnymi agencjami i biurami podróży w 14 krajach Unii Europejskiej, a także z siedmioma liniami lotniczymi. Program skierowano do osób w wieku powyżej 55 lat zamieszkałych w krajach członkowskich UE (z wyłączeniem

\footnotetext{
5 Funkcjonujący w latach od 1982 program IMSERSO jest programem wakacji dla osób starszych w ramach Instytutu Osób Starszych i Opieki Społecznej w Hiszpanii. Rocznie bierze w nim udział około 1 mln osób (KOSMACZEWSKA 2010, szerzej o programie IMSERSO także GÓRSKA 2010).
} 
Hiszpanii, Niemiec, Wielkiej Brytanii, Szwecji, Finlandii, Estonii, Litwy i Łotwy) - rys. 1.

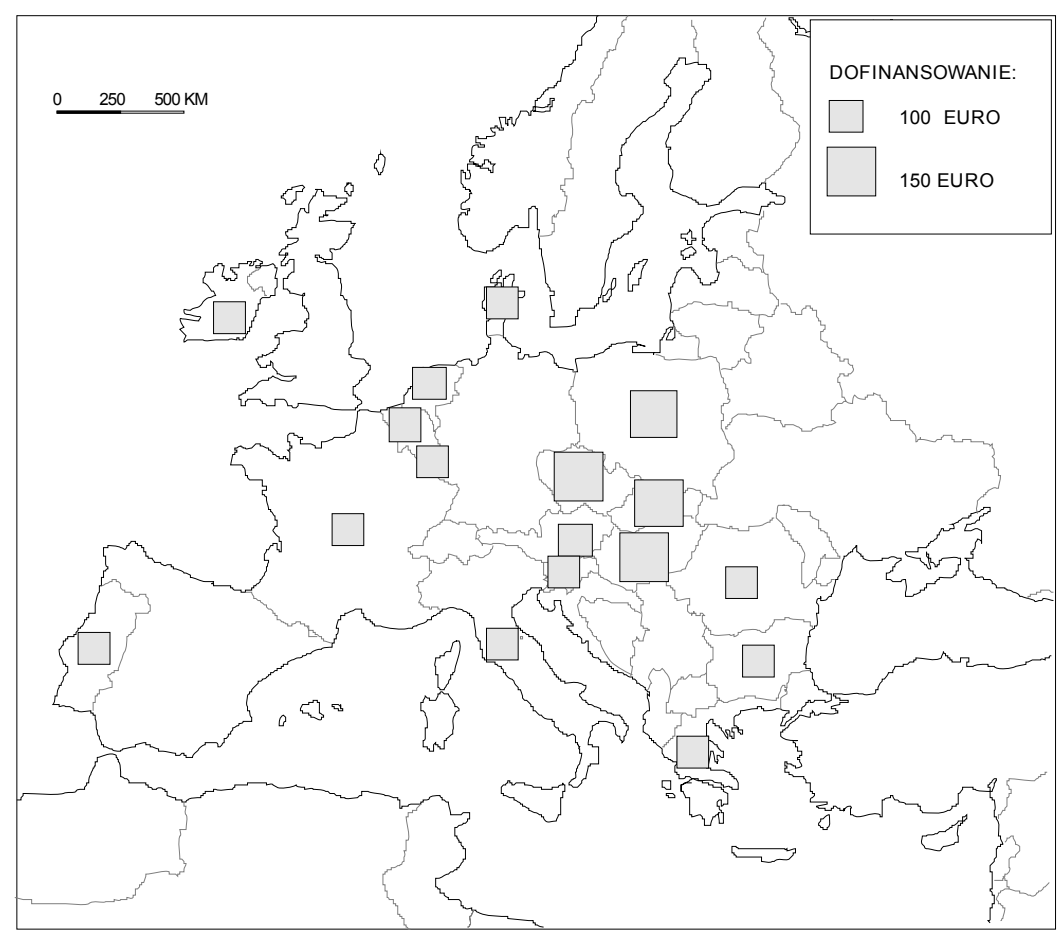

Rys. 1. Kraje Unii Europejskiej objęte programem Europe Senior Tourism od października 2009 do kwietnia 2010 r.

Źródło: opracowanie własne na podstawie www.europeseniortourism.eu

Łącznie przygotowano 80 tys. miejsc na sezon od października 2009 do kwietnia 2010 r. Wyjazdy mogły mieć różną długość - od 8-dniowych (siedem noclegów), poprzez 15-dniowe (14 noclegów), 22-dniowe (21 noclegów) do 29-dniowych (28 noclegów). Oferta obejmowała: koszty podróży w obie strony, zakwaterowanie ze śniadaniami oraz obiadokolacjami, transfery pomiędzy lotniskiem i hotelem $\mathrm{w}$ miejscu pobytu $\mathrm{w}$ dniu przyjazdu i wyjazdu, program rozrywkowy oraz ubezpieczenie. Programem objęto ponad 50 nadmorskich hoteli czterogwiazdkowych. W projekcie wzięły udział dwa regiony Hiszpanii: Wyspy Baleary (Majorka, Minorka i Ibiza) oraz Andaluzja (Costa del Sol i Costa de La Luz). Maksymalny koszt wyjazdu ustalony przez stronę hiszpańską wyniósł od 365 euro za pobyt najkrótszy (8-dniowy) do 
855 euro za pobyt najdłuższy (29-dniowy) ${ }^{6}$. Co istotne, rząd hiszpański oraz rządy regionów Andaluzji i wysp Balearów pokrywały część kosztów kwotą 100 lub 150 euro (w zależności od kraju zamieszkania ${ }^{7}$ ). Warto przypomnieć, że z perspektywy Hiszpanii istotnym celem projektu była reaktywacja działalności gospodarczej w hiszpańskich centrach turystycznych poza sezonem, dzięki aktywnej polityce zatrudnienia, która utrzymywałaby stare i tworzyła nowe miejsca pracy.

Według dostępnych danych z edycji programu EST w sezonie 2009/2010 skorzystało 45 tys. Europejczyków ${ }^{8}$. Ogółem udzielono ponad 370 tys. noclegów. W analizowanym okresie Hiszpanie zainwestowali w opisany program łącznie 5,3 mln euro, w tym $22 \%$ pochodziło od administracji hiszpańskiej, a 78\% z innych źródeł (głównie regionalnych). Każde zainwestowane 1 euro dało 1,55 euro. Według tych szacunków program EST przyniósł 29 mln euro, z tego 22,5mln euro zostało w Hiszpanii. Symptomatyczne, że według prowadzonych badań ankietowych dziewięciu na 10 badanych uczestników EST nigdy wcześniej nie było w Hiszpanii (www.ec.europa.eu;www.europeseniortourism.eu).

\section{Polscy seniorzy w ramach Europe Senior Tourism}

Wśród polskich partnerów pierwszej edycji programu EST znalazły się m.in. współpracujące z hiszpańskim touroperatorem Rainbow Tours, Ecco Holiday, Exim Tours, Watra Travel, Jaguar Travel, Lufthansa City Center - Katowice, Invitatio, Flugo i Biuro Podróży Małgorzaty Kruppe. Partnerem wspierającym wdrażanie na terenie Polski projektu rządu Hiszpanii był ponadto Uniwersytet Trzeciego Wieku SGH.

W sezonie 2009/2010 Polacy mieli do dyspozycji 10 tys. z 80 tys. miejsc w czterogwiazdkowych hotelach w kurortach na Półwyspie Iberyjskim i popularnych wyspach - Majorce i Ibizie. Pod względem liczebności byli trzecią - po mieszkańcach Grecji i Włoch - w gronie 15 nacją która skorzystała z subwencjonowanych wycieczek. W sumie, na wypoczynek poza szczytem

\footnotetext{
6 Ostateczne ceny sprzedaży ofert EST w sezonie 2009/2010 wynosiły: 8 dni - 365 euro, 15 dni 524 euro, 22 dni - 700 euro, 29 dni - 855 euro. 150 euro.

7 Beneficjenci z Czech, Polski, Słowacji i Węgier otrzymali najwyższą kwotę dofinansowania, tj.

${ }^{8}$ Liczba ta byłaby większa gdyby nie m.in. skasowane 6100 rezerwacji w kwietniu 2010 r. związane z zakłóceniami w ruchu lotniczym, jakie spowodował wybuch islandzkiego wulkanu Eyjafjoell.
} 
sezonu wyjechało z Polski 7102 osoby (dla porównania - z Czech, Słowacji i Węgier łącznie jedynie 627 osób) ${ }^{9}$. Większość, prawie 82\% (5811), wybrało Andaluzję, 1291 osób poleciało na Baleary - rys. 2.

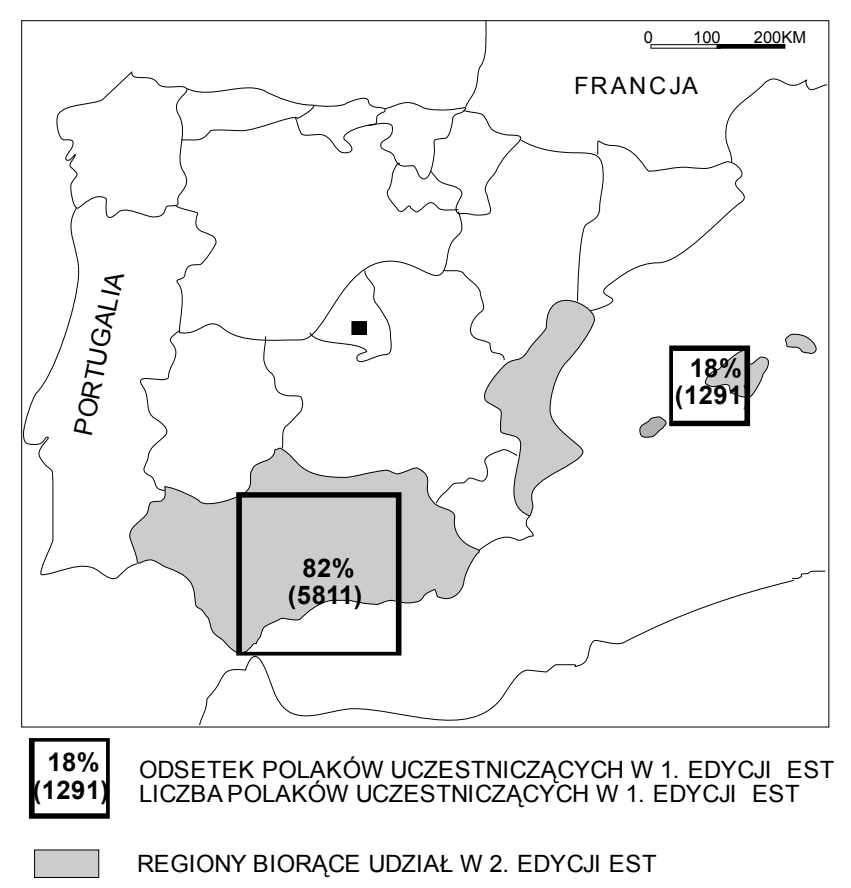

Rys. 2. Uczestnictwo polskich seniorów w Europe Senior Tourism w sezonie 2009/2010 oraz regiony biorące udział w drugiej edycji EST Źródło: Opracowanie własne na podstawie danych www.ec.europa.eu

Oficjalne dane UNWTO pokazują że w 2009 r. Hiszpanię odwiedziło 52,2 mln turystów zagranicznych, tj. prawie $9 \%$ mniej niż w roku poprzednim. Nadal jednak pozostała 3. w skali świata najliczniej odwiedzanym krajem przez cudzoziemców. Polacy stanowili wśród nich jedynie niecały $1 \%$ turystów zagranicznych (www.world-tourism.org). Warto zauważyć, że od 2003 r., w którym otwarto Biuro Radcy ds. Turystyki Ambasady Hiszpanii w Polsce, liczba turystów polskich w Hiszpanii wzrosła ponadtrzykrotnie. W roku $2008 \mathrm{w}$ hotelach w Hiszpanii zameldowało się prawie 359 tys. turystów z Polski. W 2009 roku było to prawie 366 tys. turystów. W 2010 r. do

${ }_{9}^{9}$ Dla porównania, w 2009 r. według danych IT w wyjazdach zagranicznych uczestniczyło około 100 tys. polskich seniorów. 
końca lipca zameldowało się ponad 207 tys. obywateli Polski. Symptomatyczne, że w okresie od stycznia do października 2009 r. był to jedyny rynek, oprócz Stanów Zjednoczonych, który odnotował wzrost turystów $(2,1 \%)$ (www.europeseniortourism.eu).

Według raportu finalnego Calypso program EST został bardzo dobrze przyjęty. Jesienią $2010 \mathrm{r}$. ruszyła druga edycja tego projektu, w ramach której przygotowano nieco więcej miejsc. Do programu dołączył kolejny region Walencja. W sumie dopłatami objętych zostanie 80 tys. miejsc w Andaluzji, 20 tys. na Balearach i 16 tys. $\mathrm{w}$ rejonie Walencji ${ }^{10}$. W stosunku do pierwszej edycji zmodyfikowano strukturę procedur rezerwacyjnych (każde biuro dysponuje kontyngentem miejsc $\mathrm{w}$ samolocie i dokonuje sprzedaży do określonego limitu), wprowadzona została możliwość wyjazdu (także dofinansowanego) $\mathrm{z}$ osobą towarzyszącą $\mathrm{w}$ dowolnym wieku, a cena maksymalna ustalona na tę edycję przez rząd Hiszpanii jest nieco wyższa (393 euro za ośmiodniowy pobyt). Ze strony polskiej umowy podpisało osiem biur podróży ${ }^{11}$ (Neckermann Polska, Rainbow Tours, Watra Travel, Euro 90 Travel, Exim Tours, Kruppe, Invitatio i Bee Free). Biorące udział w projekcie polskie biura spodziewają się znacznego wzrostu liczby uczestników w odniesieniu do pierwszej edycji programu. Według hiszpańskich szacunków, w sezonie 2010/2011 z programu skorzysta około 10-12 tys. Polaków.

\section{Korzyści projektu Calypso z perspektywy polskiego seniora Efekt Calypso}

Pozostając poza rozważaniami o skutkach programu EST dla strony organizatorów - zarówno hiszpańskiej jak i polskiej12, warto zastanowić się nad efektami tego programu dla polskich seniorów. Powodem jest przede wszystkim precedensowy charakter podjętego przedsięwzięcia, m.in. czynne zaangażowanie $\mathrm{w}$ nie najwyższych struktur unijnych i ich polskich odpo-

\footnotetext{
10 Od października 2010 r. program obejmuje hotele na Costa del Sol, Costa de la Luz, w Almerii i Grenadzie (Andaluzja), na Majorce, Minorce i Ibizie, Benidorm, Gandia i Peñiscola (Region Walencji).

${ }^{11}$ Biorące udział w programie polskie biura sprzedają tygodniowe wyjazdy na Costa del Sol i Costa de la Luz w cenie około 1700 zł za osobę z darmowym dodatkowym ubezpieczeniem od następstw nieszczęśliwych wypadków i chorób przewlekłych.

12 Wśród wymiernych korzyści dla polskich kontrahentów jest widoczny wzrost liczby seniorów wśród klientów biur uczestniczących w programie, np. Rainbow Tours (793 osoby w ramach programu w 2009 - tj. 20\% wzrost oferty do Hiszpanii), Neckermann Polska (do 10\%), Watra Travel (ok. 1 tys. osób), Exim Tours (planował wysłać w 2010 r. pięć razy więcej seniorów niż w sezonie ubiegłym).
} 
wiedników, które w szeroko zakrojonej akcji informacyjnej pełniły społeczną rolę niejako gwaranta wiarygodności i bezpieczeństwa dla tak nieufnego klienta, jakim jest senior $\mathrm{w}$ trudnym dla rynku turystycznego kryzysowym roku 2009.

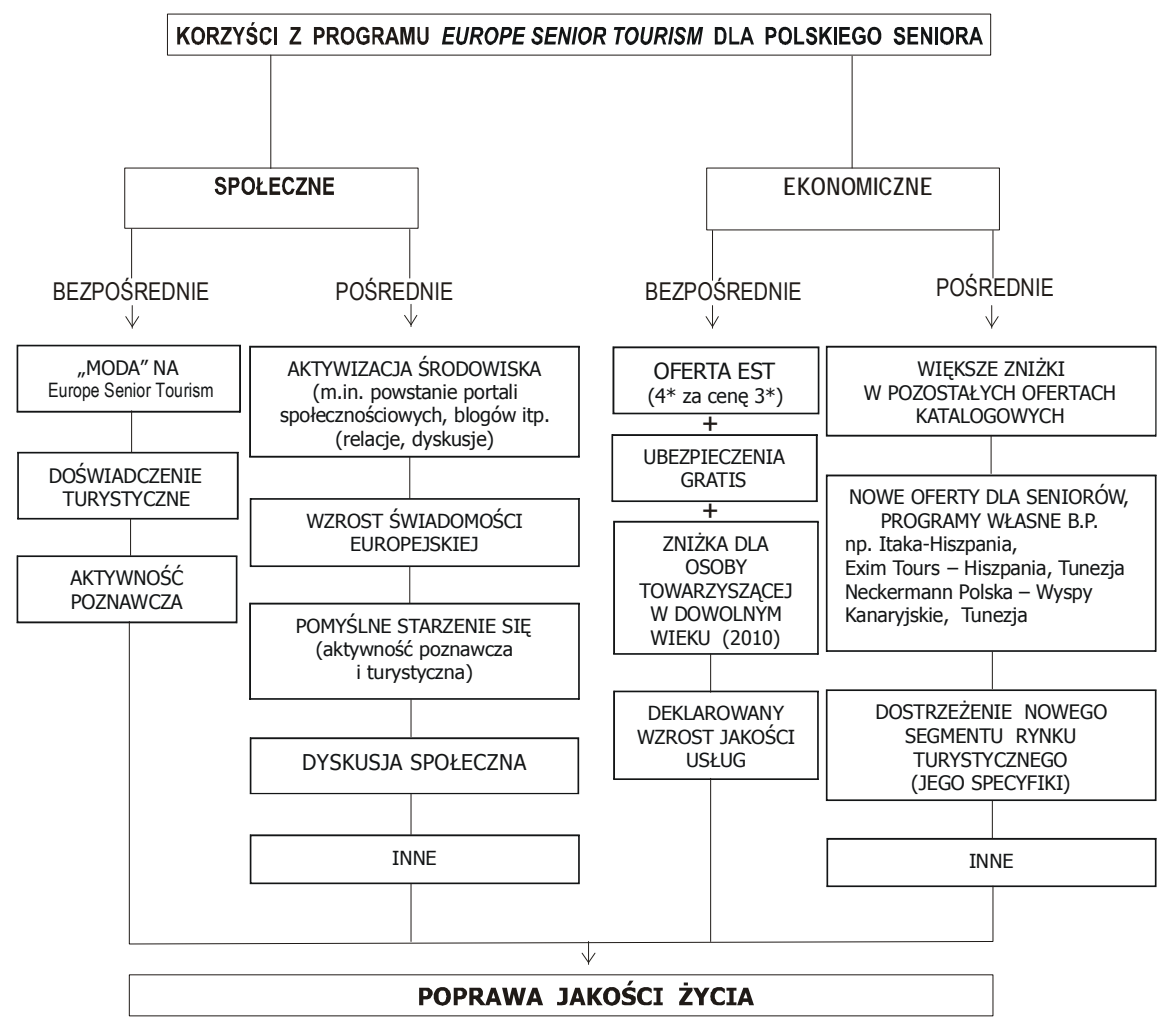

Rys. 3. Korzyści ekonomiczne oraz społeczne programu EST dla polskiego seniora Źródło: opracowanie własne

W perspektywie polskiego seniora pierwsza edycja programu EST przyniosła wiele korzyści. Można je umownie uporządkować w dwie grupy. Pierwszą stanowią korzyści o wymiarze ekonomicznym - odnoszące się głównie do oferty, drugą grupę można określić jako korzyści społeczne - rys. 3.

W odniesieniu do pierwszej grupy wychodząc od podstawy, jaką stanowi sama oferta EST, którą - upraszczając - można określić jako czterogwiazdkowe świadczenia $\mathrm{w}$ cenie trzygwiazdkowych, polscy kontrahenci najczęściej dołączają darmowo (w 2010 r.) do oferty podstawowej pakiet 
ubezpieczeń (m.in. od chorób przewlekłych, następstw nieszczęśliwych wypadków), zaś w całej europejskiej drugiej edycji programu dodano zniżkę dla osoby towarzyszącej w dowolnym wieku. Jednocześnie od 2009 r., niezależnie od EST na sezon październik-kwiecień, polskie biura podróży przygotowały zdecydowanie więcej ofert dla seniorów. Część z nich ponadto na wzór EST opracowało własne programy (nierzadko o zbliżonej nazwie) pozyskując samodzielne dofinansowania $\mathrm{w}$ wybranych regionach basenu Morza Śródziemnego (np. Itaka - Hiszpania, Exim Tours - Hiszpania, Tunezja, Neckermann Polska - Wyspy Kanaryjskie, Tunezja). Seniorzy uzyskali także zdecydowanie większe zniżki w pozostałej ofercie katalogowej. Konsekwencją jednocześnie podjętej przez seniorów krytycznej dyskusji nad nie zawsze zadowalającą jakością świadczonych usług ${ }^{13}$ podczas pierwszej edycji programu, co być może wynikało m.in. z innych przyzwyczajeń i oczekiwań (np. tłumaczenia na język polski przewodników w obiektach turystycznych) jest rotacja $\mathrm{w}$ obrębie polskich kontrahentów i deklarowany wzrost jakości usług w drugiej edycji. Działania te wskazują na stopniowe dostrzeganie i docenianie polskich seniorów jako nowego segmentu rynku turystycznego.

W zakresie korzyści społecznych można wskazać swoistą "modę" na EST, która jest widoczna chociażby w licznych relacjach (tzw. efekt demonstracji) i dyskusjach prowadzonych na wielu nowo powstałych portalach społecznościowych, blogach itp. Dowodzą one ponadto wzrostu zainteresowania innymi kulturami (aktywność poznawcza) i narastania doświadczenia turystycznego. Wszystko to sprzyja zarówno aktywizacji i integracji przynajmniej części analizowanego środowiska (zwiększaniu więzi wewnątrzpokoleniowej), jak i tworzeniu interakcji społecznych, które stopniowo otwierają pożądany kierunek w debacie (dyskusji) społecznej nad potrzebami oraz problemami współczesnych seniorów, w tym w zakresie turystyki i rekreacji. Warto wspomnieć, że wzrost świadomości wśród seniorów własnych praw, jak i odwagi mówienia o nowych oczekiwaniach jest związany m.in. z pojawieniem się i propagowaniem koncepcji pomyślnego starzenia się (succesfull

13 Analiza komentarzy na forach internetowych oraz wskazania MOKRAS-GRABOWSKIEJ (2010) pokazały, że najwięcej zastrzeżeń i reklamacji dotyczyło pracy rezydentów oraz przebiegów transferów. Na podstawie przeprowadzonych w ramach programu EST badań ankietowych zadowolenie polskich uczestników I edycji projektu oszacowano na poziomie 8,2 (w dziesięciostopniowej skali, gdzie 1 - bardzo niezadowolony, 10 - bardzo zadowolony). Podobnie krytycznie (jakkolwiek i tak na zadawalającym poziomie oceny dobrej) ocenili program jedynie Holendrzy, zaś średnie ocen ankietowanych turystów z pozostałych krajów wahały się od 8,8 do 9,8 (Evaluation of the profiltability... 2010, za: MOKRAS-GRABOWSKA 2010). 
ageing ${ }^{14}$, która w ostatnich latach pod wpływem WHO coraz częściej utożsamiana jest $\mathrm{z}$ aktywnym starzeniem się (active ageing) - (SZUKALSKI 2006).

Turystyka i rekreacja są tymi formami aktywności (fizycznej, społecznej i poznawczej), które doskonale wpisują się w tę koncepcję. Z kolei analizowany w niniejszym opracowaniu program Europe Senior Tourism, jako oferta stymulująca - podtrzymująca, a przede wszystkim zachęcająca ${ }^{15}$ do aktywności turystycznej polskich seniorów, jest zdaniem autorki ciekawym, chociaż wcale nie nowym pomysłem współczesnej turystyki społecznej. Bez stosownych badań trudno wyważyć, które aspekty - korzyści ekonomiczne czy społeczne, mają dla polskich seniorów większe znaczenie (oraz czy część w ogóle jak dostrzegana).

STAN AKTUALNY

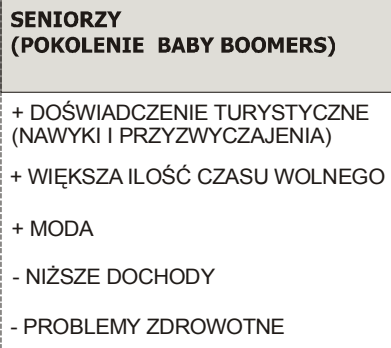

Rys. 4. Zmiana modelu turystyki europejskich seniorów - tzw. efekt Calypso Źródło: opracowanie własne

STAN OCZEKIWANY

\begin{tabular}{l|l|}
\cline { 2 - 2 } $\begin{array}{l}\text { POPULARYZACJA KONCEPCJI } \\
\text { AKTYWNEGO I POMYŚLNEGO } \\
\text { STARZENIA SIĘ }\end{array}$ & \multicolumn{1}{|c|}{ TZW. EFEKT CALYPSO } \\
\hline PROMOCJA ZDROWIA & WYJAZDY TURYSTYCZNE \\
AKTYWIZACJA ŚRODOWISKA & W SEZONIE NISKIM \\
$\begin{array}{l}\text { PROGRAMY TURYSTYKI } \\
\text { SPOKECZNEJ } \\
\text { (tj. EST, IMSERSO) }\end{array}$ & $\begin{array}{l}\text { UTRZYMANIE LUB WZROST } \\
\text { DOTYCHCZASOWEJ }\end{array}$ \\
& WKTYWOŚCI TURYSTYCZNEJ \\
\hline
\end{tabular}

Trudno także ocenić, czy program ten przyniesie trwałe - pożądane (w świetle koncepcji pomyślnego starzenia się) zmiany w aktywności poznawczej i turystycznej tej grupy (rys. 4). Czy będzie to tylko promocja sprzedaży kształtująca czasowo popyt turystyczny wśród beneficjentów, czy można będzie mówić o społecznym tzw. „efekcie Calypso”"16, który autorka rozumie 14 Jedna z ważniejszych we współczesnej psychologii gerontologicznej koncepcji - pomyślnego/ak-
tywnego starzenia się (ang. succesful ageing) (STRAŚ-RoMANOWSKA 2002). W rozumieniu tej koncepcji na
gruncie polityki społecznej i nauk społecznych szczególny nacisk położony jest na zachowanie zdrowia,
uczestnictwo w życiu społecznym, możliwość samorealizacji i zdolność poznawczą.
15 Jak wskazano wcześniej, zdecydowana większość uczestników programu była pierwszy raz
w Hiszpanii. Zatem większość z uczestników to „nowi” klienci. Z wywiadu autorki ze słuchaczami Uni-
wersytetu Trzeciego Wieku przy WSTH w Łodzi (w dniu 27.10 .2010 r.) wynika, że główną zachętą do ta-
kiego wyjazdu jest bardziej przystępna cena i wiarygodność oferty.
${ }^{16}$ Nimfa Kalipso dla jednych gościła, dla innych więziła u siebie Odyseusza przez siedem lat. Kalipso
ratując mu życie, karmiąc nektarem i ambrozją chciała jego wiecznej młodości i nieśmiertelności, by zatrzy- 
jako trwałą zmianę (ewolucję) modelu wypoczynku na ukierunkowany w stronę pomyślnego starzenia się (większej aktywności turystycznej, rekreacyjnej i poznawczej), dokonaną m.in. przy wykorzystaniu turystyki społecznej i związanego z nią marketingowego przyciągania turystów seniorów do obszarów recepcji poza sezonem turystycznym.

\section{BIBLIOGRAFIA}

Calypso study. Final Report,2010, Ramboll Management Consulting, Détente consultants, Labour Asociados, European Commission, DG Enterprise and Industry.

Calypso study on social tourism - Poland, 2010, Ramboll Management Consulting, Détente consultants, Labour Asociados, European Commission, DG Enterprise and Industry.

Działania na rzecz rozwoju turystyki społecznej w Polsce, 2010, raport MSiT, Warszawa.

Europa - najpopularniejszy kierunek turystyczny na świecie - nowe ramy polityczne dla europejskiego sektora turystycznego, $\mathrm{KOM}(2010)$ 352, Bruksela.

GóRSKA E., 2010, Turystyka społeczna jako forma aktywizacji rynków turystycznych na przykładzie programów turystyki społecznej w Hiszpanii, "Acta Scientiarum Polonorum. Oeconomia", No. 9 (4), s. 133-142.

KOSMACZEWSKA J., 2010, Turystyka socjalna jako narzędzie minimalizowania negatywnych skutków sezonowości w regionach turystycznych, Zeszyty Naukowe Uniwersytetu Szczecińskiego, nr 591, s. 149-158.

MOKRAS-GRABOWSKA J., 2010, Program „Europe Senior Tourism” - założenia, realizacja, efekty ekonomiczne, [w:] A. Stasiak (red.), Turystyka społeczna w regionie tódzkim, Wyd. WSTH w Łodzi, Łódź, s. 71-88.

STRAŚ-ROMANOWSKA M., 2002, Starzenie sie jako kontekst rozwoju duchowego człowieka, [w:] W. Wnuk (red.), Ludzie starsi w trzecim tysiacleciu. Szanse - nadzieje - potrzeby, UTW, Wrocław, s. 27-34.

SZUKALSKI P., 2006, Zagrożenie czy wyzwanie - proces starzenia się ludności, „Polityka Społeczna”, nr 9, s. 6-10.

ŚNIADEK J., 2007, Konsumpcja turystyczna polskich seniorów na tle globalnych tendencji w turystyce, "Gerontologia Polska", t. 15, nr 1-2, s. 21-30.

http://www.ec.europa.eu.

http://www.europeseniortourism.eu (14.09.2010).

http://www.world-tourism.org (15.09.2010).

mać go dla siebie. Ten epizod z eposu Homera „Odyseja” zawiera m.in. wątki podróży, gościnności, beztroski, rozrywki ale też zniewolenia, tęsknoty za domem, czy lęku przed samotnością.

204 WARSZTATY Z GEOGRAFII TURYZMU 